\title{
A real-time PCR quantitative analysis of the Venturia inaequalis cytb gene G143A mutation and its prevalence in the Czech Republic
}

\author{
P. Jaklova, J. Kloutvorova and R. Cmejla \\ Research and Breeding Institute of Pomology Holovousy Ltd., Horice, Czech Republic
}

\section{Summary}

Venturia inaequalis (Cooke) G. Winter (1875) is a fungal pathogen that causes a disease in apples known as apple scab, which is a major source of economic losses for apple growers. To contain the pathogen, fungicides have been usually applied, often from the strobilurin family. Unfortunately, only two years after the introduction of strobilurin fungicides, resistant $V$. inaequalis populations appeared, and a substitution of glycine at position 143 with alanine (G143A) in the mitochondrial cytb gene was found to be the mutation responsible.

Many methods exist to detect this mutation, but they are generally not suitable for simple routine use, do not provide quantitative data, or are not sensitive enough. Moreover, the quality and quantity of isolated DNA from fungi may also be an issue due to the frequent presence of PCR inhibitors.

A new real-time PCR-based assay was therefore designed that can detect $0.1 \%$ of the G143A mutation in a wild type background and vice versa; in parallel, DNA isolation was optimized, using 10 million conidia in a suspension prepared from leaves harvested in orchards instead of the commonly used scab mycelia.

The assay was then used for screening of the resistant $V$. inaequalis in orchards. The G143A mutation was present in all conventional and organic orchards tested, and in the vast majority it was present at nearly or at $\mathbf{1 0 0 \%}$, indicating that the mutation does not likely affect the fitness of $\mathrm{V}$. inaequalis and the mutation persists over time. Furthermore, the G143A mutation (average $2.3 \%$ ) was also observed in $\mathrm{V}$. inaequalis isolates harvested from alley trees along roads, implying that the mutation also occurs naturally at low levels.

Keywords

apple, conidia, DNA isolation, QoI fungicides, mutation screening, resistance to fungicides, strobilurin fungicide

\section{Introduction}

The fungus Venturia inaequalis (Cooke) G. Winter (1875) (anamorph - Spilocea pomi Fr., 1825) is one of the most harmful fungi infesting apple orchards worldwide, causing the disease known as apple scab (MacHardy, 1996). The fungus mainly infects leaves and fruits, causing scab-like lesions that progress to corky spots. The resulting spoiled fruit loses its market value, leading to substantial economic losses (Agrios,

\section{Significance of this study}

What is already known on this subject?

- Venturia inaequalis (Cooke) G. Winter (1875) is one of the most harmful fungal pathogens that apple growers must deal with, causing substantial economic losses if not handled properly. However, several years after strobilurin fungicides were introduced to field practice to combat $V$. inaequalis, resistance appeared. Subsequent studies showed that the resistance is mainly caused by a glycine-to-alanine substitution (G143A) in the mitochondrial cytb gene, and detection methods were devised.

What are the new findings?

- We developed a new real-time PCR method that is suitable for routine laboratory use to quantify the presence of the G143A mutation in V. inaequalis cytb gene with a sensitivity of $0.1 \%$. Concurrently, DNA isolation was optimized using a conidia suspension from leaves harvested in orchards to obtain high quality and quantity DNA for PCR analysis. Assessments of the ratio of resistant $V$. inaequalis in Czech apple orchards indicate that the G143A mutation is highly prevalent.

What is the expected impact on horticulture?

- The developed assay is highly sensitive, simple, rapid, and thus can be offered to apple growers for regular orchard monitoring to provide solid data for fungicide application management. Knowledge of the geographical distribution of resistant $V$. inaequalis populations could also be helpful to chemical companies or national plant protection authorities.

2005). The usual way to fight the pathogen is through the use of fungicides, and proper fungicide management is thus very important to ensure a high quality produce.

Strobilurin family fungicides that belong to quinone outside inhibitors (QoI) blocking the respiratory chain in mitochondria (Ypema and Gold, 1999) have been commonly used in Europe since their registration in the late 1990s, but after only a couple of years of use, resistance to these fungicides for various fungal pathogens appeared (Sierotzki et al., 2000a, b; Gisi et al., 2002). Subsequent studies showed that the resistance stemmed mainly from mutations in the mitochondrial cytochrome $b$ gene (cytb), with a glycine substitution at positon 143 with alanine being the most prevalent (Bartlett et al., 2002; Grasso et al., 2006). 
A number of methods for general resistance testing of $V$. inaequalis have been developed, using either in vitro approaches (e.g., spore germination in the presence of fungicide, tests in drops of a fungicide solution, or mycelial growth with fungicide in the media) or in vivo (e.g., artificial infection of plants treated by fungicide, field trials; Brent and Hollomon, 2007). There are also many studies describing methods for the specific detection of the $V$. inaequalis $c y t b$ gene G143A mutation using PCR with a subsequent analysis of PCR products, using, e.g., sequencing, pyrosequencing, restriction enzyme analysis, ssDNA conformation polymorphism, or allelic discrimination (Gisi et al., 2002; Fontaine et al., 2009; Michalecka et al., 2011; Sedlak et al., 2013; Miessner et al., 2015; Turan et al., 2016; Manger-Jacob et al., 2016).

Each method has its advantages and disadvantages, but they generally do not provide quantitative results or are not suitable for routine, reliable standardized analyses of multiple samples that could be offered to growers and used for decision making. One of our goals therefore was to develop a simple real-time PCR assay that would allow the quantification of the $V$. inaequalis cytb gene G143A mutation in field samples. Knowledge of the G143A mutation ratio in an orchard might: 1) prevent the inappropriate use of strobilurin fungicides in cases where pathogen resistance has already been established; 2) prevent economic losses due to the use of an ineffective fungicide; 3 ) avoid unnecessary environmental burdens; and 4) prompt growers to apply fungicides from another chemical family with a different mechanism of action to ensure effective apple protection.

The first screening of the G143A mutation in the $V$. inaequalis cytb gene in the Czech Republic was conducted by Sedlak et al. (2013). However, the authors used a qualitative test only (an ssDNA conformation polymorphism detection method), and the work focused on individual $V$. inaequalis isolates. Another aim of the present work was therefore to use the developed assay to perform a follow up study - quantitative screening of the $V$. inaequalis cytb G143A mutation ratio in the main apple producing areas in the Czech Republic. For comparison, we chose both conventional and organic orchards as well as samples from apple trees in alleys along roads where fungicides have presumably never been used.

\section{Materials and methods}

\section{Sample collection and conidia suspension preparation}

Samples of $V$. inaequalis were collected at various sites in the Czech Republic, especially in regions with intensive apple production (Central, North and East Bohemia, and South Moravia). Wild type $V$. inaequalis populations were sampled from apple trees in gardens or along roads with no history of fungicide treatment located at least $5 \mathrm{~km}$ from commercial orchards. Orchards to be tested were of two types - conventional and organic; if available, information about the use of strobilurin fungicides was recorded. In conventional orchards, registered pesticides may be used in accordance with manufacturers' instructions; in organic orchards, only environment-friendly treatments may be applied according to the European Union Council Regulation (EC) No. 834/2007 and Commission Regulation (EC) No. 889/2008 on organic production and labelling of organic products.

Whole shoots (10-15 per orchard) with infested leaves and visible young sporulating lesions were randomly harvested. A conidia suspension was obtained by washing off 50-60 scabbed leaves using sterile water. The suspension was filtered through a mesh cloth to remove gross impuri- ties, and the conidia concentration was determined by counting in a Bürker chamber. Conidia suspensions were stored at $-20^{\circ} \mathrm{C}$ until further processing.

\section{DNA isolation, real-time PCR detection of mutated and wild type cytb gene, sequencing}

DNA isolation was performed from 10 million $V$. inaequalis conidia using an Exgene Plant SV mini kit (GeneAll) according to the manufacturer's instructions. DNA was eluted to a final volume of $50 \mu \mathrm{L}$. For specificity testing, DNA from mycelia $(50 \mathrm{mg}$ ) each of the following common fungi was also isolated: Fusarium sp., Cladosporium sp., Alternaria sp., Mucor sp., Trichoderma sp., Chaetomium sp., Marssonina coronariae, Elsinoe pyri, Monilinia fructigena, Botrytis cinerea, Epicoccum nigrum, Rhizopus stolonifera, Neofabrea alba, and Didymella lethalis.

Specific primers were designed for the PCR amplification of either the wild type or the G143A mutation in the $c y t b$ gene. For the wild type locus detection, the forward primer ATGGTCAAATGAGCCTAGGTGGT and reverse primer AAGCCTCCCCACAGAAATTCG were used; for the G143A mutation, the forward primer ATGGTCAAATGAGCCTAGTGGCT and the same reverse primer were used. PCR conditions were as follows: TopBio Blue buffer and CombiTaq (1U; TopBio) were used for PCR amplification; EvaGreen (Biotium) at $1 \times$ final concentration was used for real-time PCR quantitation; dNTPs (Genaxxon) were used at a final concentration $0.2 \mathrm{mM}$ each; primers were added at a final concentration of $0.25 \mu \mathrm{M}$; and PCR grade water was added to $20 \mu \mathrm{L}$. Two $\mu \mathrm{L}$ of isolated DNA was used as a template. The PCR reaction was carried out in a Rotor-Gene Q cycler (Qiagen), using the same PCR profile: initial denaturation at $94^{\circ} \mathrm{C} / 5$ minutes; 45 cycles consisting of: $94^{\circ} \mathrm{C} / 20 \mathrm{~s} ; 58^{\circ} \mathrm{C} / 2 \mathrm{~s} ; 72^{\circ} \mathrm{C} / 10 \mathrm{~s}$ with a fluorescence reading in the HRM channel. All samples were run in triplicates.

To perform quantitation, Ultramer ${ }^{\circledR}$ ssDNA oligonucleotides (Integrated DNA Technologies) corresponding to the wild type and the mutated $c y t b$ variant, respectively, were used as standards to construct calibration curves. In each sample, the presence of the wild type and mutated variant was absolutely quantified based on the constructed respective calibration curve using the Rotor-Gene Q software, and the ratio of the mutated variant in the mixture was calculated.

To verify the specificity of the detection system and its accuracy, a part of the cytb gene containing the G143A mutation was amplified in 20 samples using forward primer ACCTTGACCTGCCGATGTAGG and the same reverse primer as above, using the same PCR profile and PCR conditions except for replacing EvaGreen with water and using a C1000 endpoint cycler (Bio-Rad). PCR amplicons of $465 \mathrm{bp}$ were cut out from the agarose gel, purified with an Expin Combo GP kit (GeneAll) and sequenced on an AB3500 Series Genetic Analyzer using the reverse primer and BigDye Terminator RR Kit v 3.1 and BigDye XTerminator Kit (Thermo Fisher Scientific), according to the manufacturer's instructions.

\section{Monosporic isolate preparation}

To independently evaluate the accuracy of real-time PCR quantitative results, monosporic isolates were generated from a population of $V$. inaequalis containing $50 \%$ of the G143A mutated variant based on real-time PCR results. Conidia of $V$. inaequalis harvested from sporulating lesions were transferred into sterile water, and $100 \mu \mathrm{L}$ of the suspension was spread over the surface of water agar $(2 \%$, 
Himedia) with lactic acid $(0.1 \%)$ in a Petri dish using a dry sterile stick. Agar plates were incubated overnight at room temperature. The next day, single germinating spores were transferred under a microscope to a new Petri dish with Chloramphenicol-Yeast-Glucose-Agar medium (4\%, Himedia) to eliminate environmental contaminations. Plates were then incubated at room temperature for 25 days. Afterwards, pieces of growing mycelia were replanted to a new plate containing Potato-Dextrose-Agar medium (3.9\%, Himedia), and incubated at room temperature until a large enough colony was obtained for the DNA isolation.

DNA was isolated from individual colonies (50 mg) using the protocol described above, and the presence of the wild type or G143A variant was analyzed using both the real-time PCR assay and sequencing as described above.

\section{Results}

\section{Quantitative real-time PCR detection of the cytb G143A mutation}

For quantitative assessment of the $V$. inaequalis cytb G143A mutation, a new real-time PCR assay detecting the G143A mutation in a conidia suspension was developed. The method relies on the absolute quantification of the wild type (WT) and mutated (MUT) cytb variants in each sample, allowing a calculation of the MUT variant ratio in the original sample.

First, the designed assay was tested to discriminate between the WT and MUT variants using synthetic DNA controls. It was shown that used primers and PCR conditions led to a specific amplification of either the WT or the MUT variant. After successfully testing the assay with synthetic controls, DNA isolated from $V$. inaequalis was used as a template. For this purpose, 30 monosporic isolates from different locations were generated, DNA isolated, and independently analyzed by the real-time PCR assay and sequencing to determine the presence or absence of the G143A mutation. In all cases, sequencing corroborated the real-time PCR results,

Figure 1. Sensitivity of WT and MUT variant detection. A) Both MUT and WT variants are efficiently amplified regardless of their mutual ratio. B) The sensitivity of the assay is $10^{-3}$.
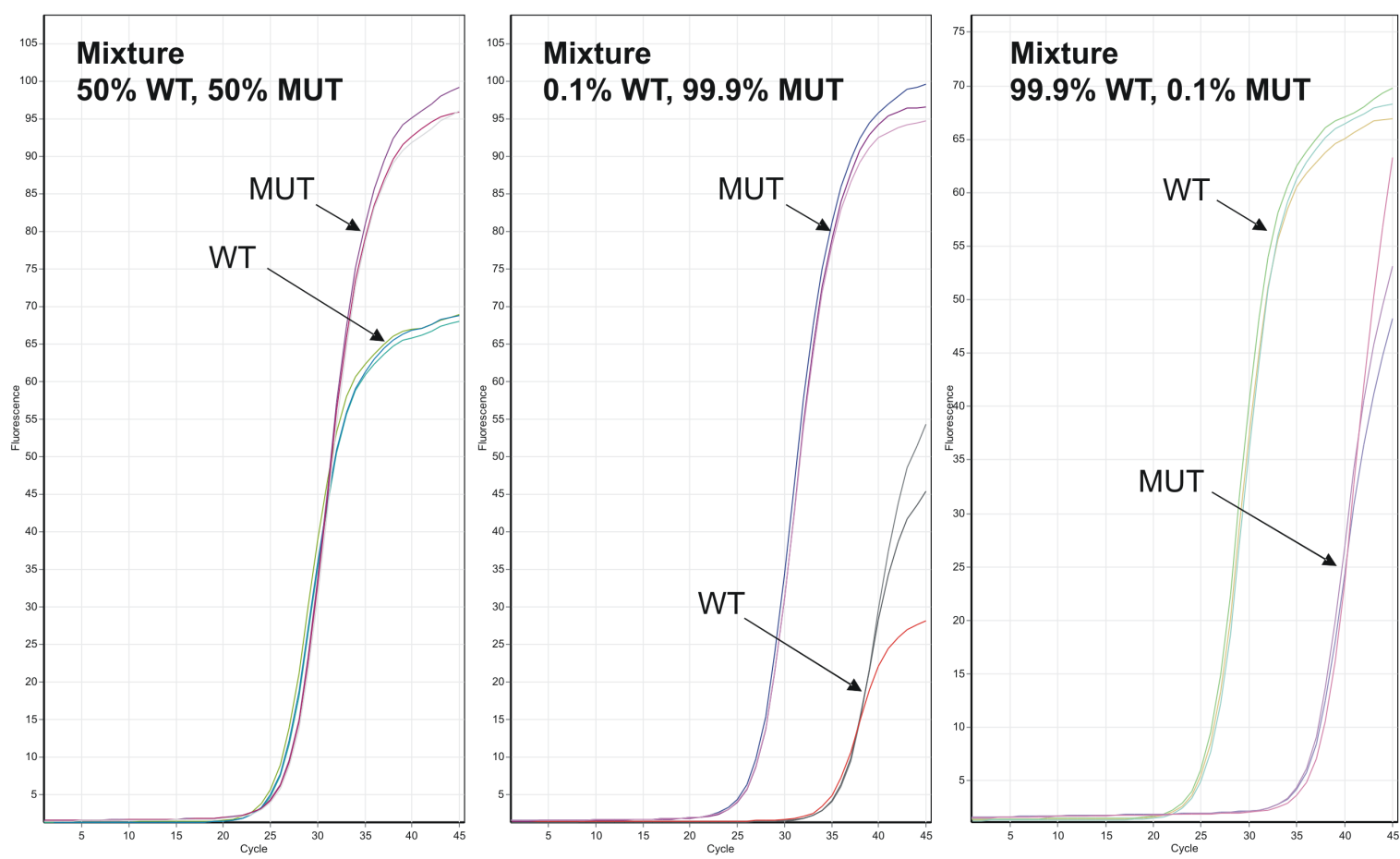
whether WT or MUT (data not shown). Then, the specificity of the assay was tested using isolated DNA from common fungi (Fusarium sp., Cladosporium sp., Alternaria sp., Mucor sp., Trichoderma sp., Chaetomium sp., Marssonina coronariae, Elsinoe pyri, Monilinia fructigena, Botrytis cinerea, Epicoccum nigrum, Rhizopus stolonifera, Neofabrea alba, and Didymella lethalis). For all species, real-time PCR gave negative results for both MUT and WT cytb gene amplicons, indicating that the assay is highly specific for the $V$. inaequalis cytb gene only (data not shown).

To determine the sensitivity of the assay, mixtures of WT and MUT synthetic standards in various ratios were prepared. As shown in Figure 1, the assay reliably detects both the WT and MUT variants at a mutual ratio of at least $0.1 \%$.

To verify the accuracy of the real-time PCR method, two other methods were employed. First, monosporic isolates were prepared from a conidia suspension in which $50 \%$ of the MUT variant was detected by real-time PCR. Eight colonies were grown, and in four (50\%) of them the MUT variant was detected while in the other four colonies the WT variant was detected, confirming the ratio that was initially calculated using the real-time PCR assay. Second, DNA used for the real-time PCR quantitation was also used for the amplification of the mutated $c y t b$ locus for an independent sequencing analysis. As expected, peaks in the sequence chromatogram for WT and MUT variants overlapped with the same intensity, indicating the presence of both variants at relatively the same concentration (data not shown).

The average amplification efficiency for the WT variant was $0.91 \pm 0.02(n=10)$, and for the MUT variant $0.86 \pm 0.02$ $(n=10)$, respectively. DNA was isolated from various number of conidia ranging from 1 to 50 million. Optimal number of conidia for DNA isolation was set to 10 million conidia, which gives an average Ct value of $22.57 \pm 1.39(n=57)$ for pure WT or MUT conidia suspensions. The average DNA concentration was $14.3 \pm 5.4 \mathrm{ng} \mu \mathrm{L}^{-1}$ and purity measured by A260/ A280 $\mathrm{nm}$ absorbance ratio $1.96 \pm 0.18(n=10)$.

\section{Samples collected in orchards}

Samples were collected in conventional orchards $(n=41)$ and organic orchards $(n=5)$. Sampling details for conventional orchards are given in Table 1. In all samples, the mutated variant clearly dominated: $95 \%$ of samples contained more than $90 \%$ of the G143A mutated variant, while in only two samples (4.9\%) the mutated variant was present at less than $90 \%$ (80.5\% - Bzenec; $86.3 \%$ - Vlastibořice). In all orchards where information was available, strobilurin fungicides had been used either alone or in combination with other fungicides.

The geographical distribution of sampling sites is shown in Figure 2. Samples were taken primarily from regions with intensive apple production.

A summary of results for organic orchards is shown in Table 2. In all orchards, a high penetration of the G143 mutation of more than $90 \%$ was observed, in spite of the fact that no strobilurin fungicides had been used there for at least five years. On the other hand, all orchards except for "Obříství" had a history of strobilurin fungicides use before management was changed to organic. The "Obříství" orchard was established in 2014, and though fungicides had not been used there since, the $V$. inaequalis population contained the G143A mutated cytb gene at nearly 35\%, very likely due to an apple tree and ornamental plant nursery in the close vicinity.

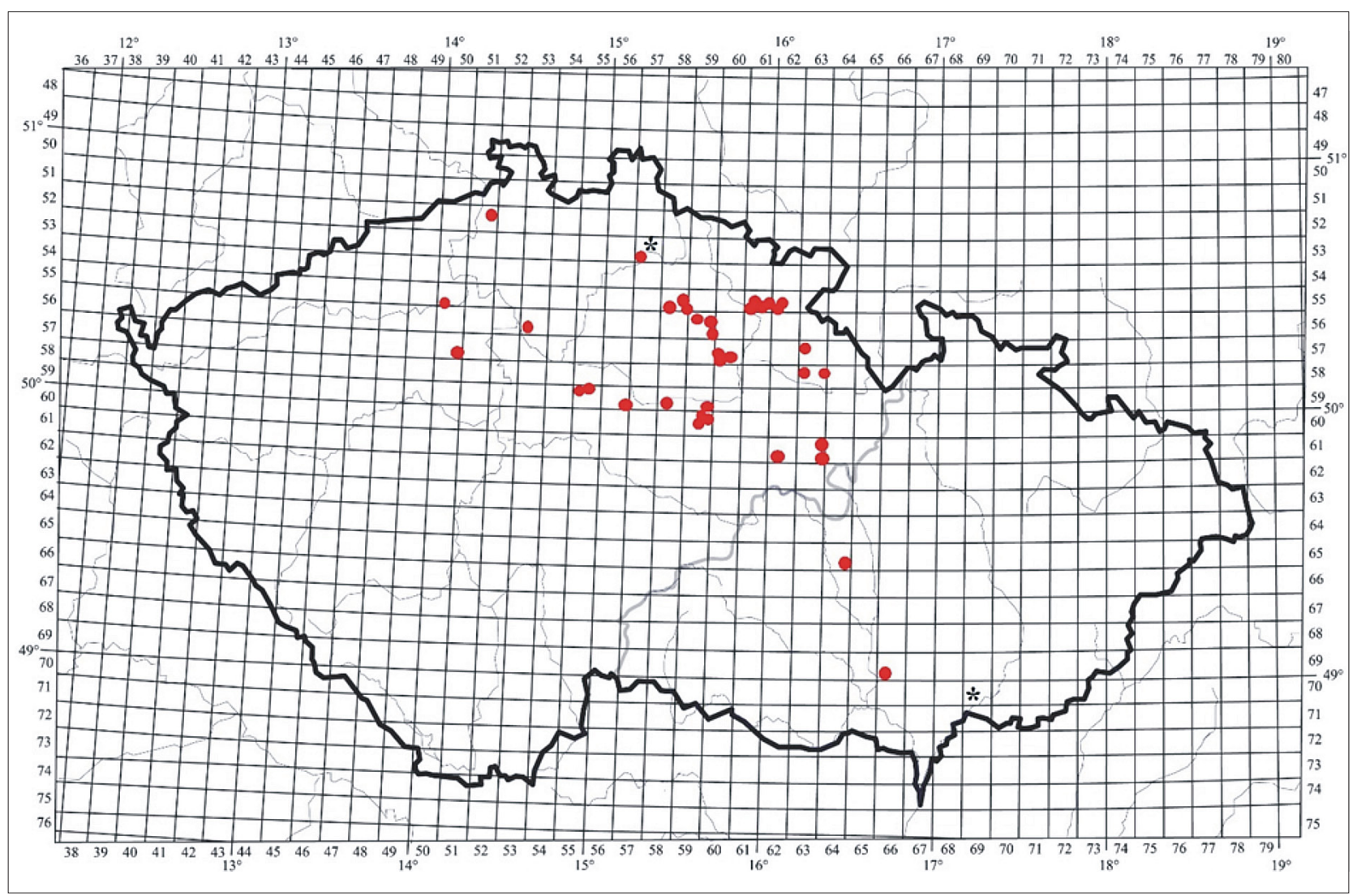

FIGURE 2. Geographical locations of $V$. inaequalis sampling. Sampling was carried out in the Czech Republic, mainly in regions with an intensive apple production. $\bullet$ denotes samples containing $>90 \%$ of the mutated cytb variant; ${ }^{*}$ indicates samples with $80-90 \%$ of the mutated $c y t b$ variant. 
TABLE 1. Summary of samples collected in conventional orchards.

\begin{tabular}{|c|c|c|c|}
\hline Locality & Region & History of strobilurines use & $\%$ of MUT cytb gene variant \\
\hline Benešov nad Ploučnicí & North & Last time in 2013 & 100 \\
\hline Klapý & North & Yes & 99.73 \\
\hline Bříství & Central & Yes & 100 \\
\hline Slaný 1 & Central & Yes & 97.93 \\
\hline Slaný 2 & Central & Yes & 96.42 \\
\hline Tismice 1 & Central & NA & 96.24 \\
\hline Tismice 2 & Central & NA & 100 \\
\hline Dolany & East & Yes & 98 \\
\hline Dolany & East & Yes & 99.46 \\
\hline Dolní Újezd & East & Yes & 100 \\
\hline Domašín & East & Yes & 99.79 \\
\hline Choltice & East & Yes & 95.26 \\
\hline Choustníkovo Hradiště 1 & East & Last time in 2008 & 96.74 \\
\hline Choustníkovo Hradiště 2 & East & Yes & 99.78 \\
\hline Kamenice & East & Yes & 100 \\
\hline Kojice & East & Yes & 99.71 \\
\hline Lužany & East & Yes & 100 \\
\hline Osík & East & Yes & 99.17 \\
\hline Ostroměř & East & Yes & 100 \\
\hline Pěnčín & East & Last time in 2004 & 99.11 \\
\hline Petrovičky & East & NA & 100 \\
\hline Probluz & East & NA & 98.81 \\
\hline Ratibořice & East & Yes & 100 \\
\hline Rychnovská Lhotka & East & Last time in 2015 & 99.29 \\
\hline Svijanský Újezd 1 & East & Last time in 2013 & 92.94 \\
\hline Svijanský Újezd 2 & East & Last time in 2013 & 98.1 \\
\hline Svinčany 1 & East & Yes & 91.98 \\
\hline Svinčany 2 & East & Yes & 98.35 \\
\hline Svinčany 3 & East & Yes & 97.83 \\
\hline Synkov & East & Yes & 98.37 \\
\hline Těchlovice & East & Last time in 2014 & 100 \\
\hline Úlibice & East & Yes & 100 \\
\hline Velký Třebešov & East & Las time in 2013 & 100 \\
\hline Vlastibořice & East & Last time in 2010 & 86.31 \\
\hline Vršovka & East & Yes & 95.91 \\
\hline VŠúO Holovousy & East & Yes & 98.26 \\
\hline Želí & East & Last time in 2014 & 100 \\
\hline Bzenec & South Moravia & Last time in 2006 & 80.52 \\
\hline Nosislav 1 & South Moravia & Yes & 98.87 \\
\hline Nosislav 2 & South Moravia & Yes & 99.78 \\
\hline Rohozec-Brt'ov & South Moravia & Last time in 2004 & 97.9 \\
\hline
\end{tabular}

NA: data not available.

TABLE 2. Summary of samples collected in organic orchards.

\begin{tabular}{lccccc}
\hline Locality & Region & $\begin{array}{c}\text { Orchard } \\
\text { established }\end{array}$ & $\begin{array}{c}\text { Start of organic } \\
\text { regime }\end{array}$ & $\begin{array}{c}\text { History of } \\
\text { strobilurines use }\end{array}$ & $\begin{array}{c}\text { \% of MUT cytb gene } \\
\text { variant }\end{array}$ \\
\hline Huntírov & North & 1996 & 2013 & Last use in 2012 & 100 \\
Obř́ství & Central & 2014 & 2014 & No & 34.61 \\
Slaný & Central & 1978 & 2007 & Last use in 2004 & 97 \\
Přední Proseč & East & 1983 & 2008 & Last use in 2013 & 94.34 \\
Žernov & East & 1983 & 2008 & Last use in 2013 & 90.28 \\
\hline
\end{tabular}




\section{cytb G143A mutation in time}

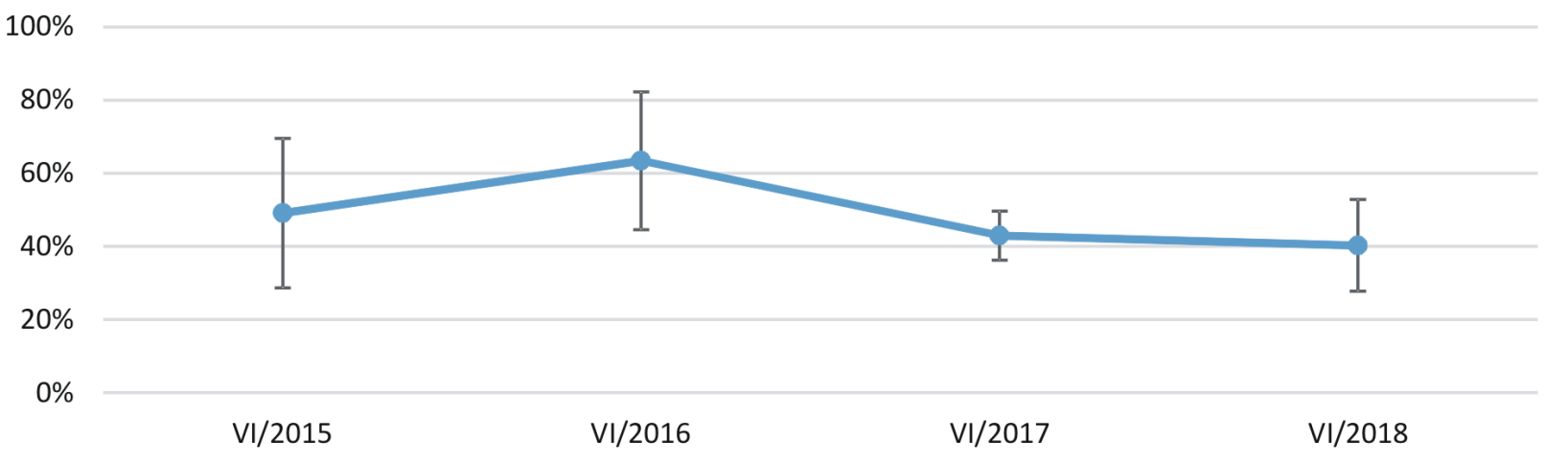

FigURE 3. Cytb G143A mutation in time. In one location, sampling was performed consecutively for four years, and the percentage of the mutated variant was analyzed.

\section{Samples collected outside orchards}

To evaluate the presence of the cytb G143A mutation in $V$. inaequalis under natural conditions, four samples were also collected from old trees growing along roads at least $5 \mathrm{~km}$ away from commercial orchards. In all trees, the MUT variant was detected at $2.3 \% \pm 1.2$ on average.

\section{The cytb G143A mutation over time}

In one location with no history of fungicide use that showed the mutated $c y t b$ variant present at $50 \%$, sampling was performed repeatedly in June for four consecutive years to study the dynamics of the presence of the G143A mutation. Results are shown in Figure 3. Over the four years, there was no dramatic change in the G143A mutated variant content in the $V$. inaequalis conidia population.

\section{Discussion}

This study focused on three aims - to develop a quantitative real-time PCR method for routine monitoring of the $V$. inaequalis cytb gene G143A mutation in orchards, to optimize DNA isolation from conidia for better handling, and to perform an initial quantitative screening in the main apple production areas in the Czech Republic.

Generally, DNA isolation and G143A mutation screening is performed from mycelium grown on leaves (scab lesions), either solely or in a pool of multiple samples. However, only a limited number of samples can be processed this way at the same time. To overcome this limitation, we decided to use a conidia suspension prepared from leaves harvested in orchards. The main advantages are: pooling conidia from hundreds of samples can easily be achieved; the conidia suspension can be simply concentrated/diluted by centrifugation; and DNA can be isolated from a defined number of conidia cells, which is important for quantitative analysis and the interpretation of results. To efficiently utilize the dynamic range of the assay (three orders of magnitude corresponding roughly to ten PCR cycles), sufficiently concentrated DNA must be prepared. Under our conditions, DNA isolated from 10 million conidia gave reliable results with an average $\mathrm{Ct}$ value of $22.57 \pm 1.39$ for pure WT or MUT conidia suspensions, which is sufficient to detect the presence of $0.1 \%$ of the MUT variant in a WT population, and vice versa.

As for the detection of the $V$. inaequalis cytb G143A mutation, many methods exist. A quantitative real-time PCR test was designed by Michalecka et al. (2011). This test relies on an allele-specific real-time PCR, utilizing three sets of primers, and exhibits the same discriminating power as our system, provided a good quality DNA is used as a template. However, the need to perform three independent PCRs lowers the processing capacity of the detection by one third in comparison with our system.

Having a standardized method for the detection of the $V$. inaequalis cytb G143A mutation, we next carried out a screening of orchards in the Czech main apple producing areas. Based on the results we conclude that:

1) In all tested conventional orchards, the mutated cytb variant is highly prevalent, usually well above $95 \%$, and in nearly one third of orchards only the MUT variant was detected. All orchards (where information was available) had a history of strobilurin fungicides use, and despite the cessation of application more than 14 years ago in some orchards, $V$. inaequalis populations have still not reverted to the wild type $c y t b$ gene. We also confirmed findings of the G143A mutation in orchards originally tested by Sedlak et al. (2013) Dolany, Petrovičky, Choustníkovo Hradiště, Kamenice, Rohozec Brt'ov, Velký Třebešov, where the cytb G143A mutation was still present at $97.9-100 \%$. The persistence of resistant $V$. inaequalis for at least six years was also observed by Fiaccadori (2018) and Frederick et al. (2014).

2) Data from organic orchards corroborate our findings from conventional orchards - even after abandoning the use of strobilurin fungicides, the MUT cytb variant is still present at nearly $100 \%$. The only exception was the four year old "Obříství" orchard, in which the V. inaequalis population contained the G143A mutated cytb gene at nearly 35\%, though fungicides has never been used there. However, resistant $V$. inaequalis may originate from an apple tree and ornamental plant nursery with strobilurin fungicides use history in the close vicinity.

3) Various mechanisms influencing the evolution of resistance to QoI fungicides were described by Gisi et al. (2002). Here we show that the cytb G143A mutation occurs naturally at a low level, $2.3 \%$ on average (apple trees along roads away from orchards), likely explaining the speed with which resistant $V$. inaequalis populations appeared worldwide after strobilurin fungicides introduction to practice.

Taking all together, a naturally existing cytb G143A mutation likely successfully propagates under selective pressure (the use of strobilurin fungicides) in $V$. inaequalis populations up to $100 \%$. Conversely, when the selective pressure ceases (Tables 1 and 2; Figure 3), the mutation persists at unchanged levels for at least 14 years, implying: that 1) the 
cytb G143A mutation does not influence the fitness of $V$. inaequalis; 2) the level of the wild type variant does not increase spontaneously; and 3) the alanine in position 143 giving $V$. inaequalis resistance to QoI fungicides represents a new wild type standard, at least in Czech apple tree orchards.

\section{Conclusion}

In summary, the assay presented here is rapid, relatively cheap, reliable, and proven in practice, and can thus be offered to growers for routine orchard monitoring to provide information valuable for the management of fungicide applications. Knowledge of the geographical distribution of resistant $V$. inaequalis populations may also be helpful to national plant protection authorities.

\section{Acknowledgments}

This work was supported by the Ministry of Agriculture of the Czech Republic, National Agency for Agricultural Research (NAZV), project QJ1510353. We thank all technicians for excellent assistance and growers for collecting and sending samples.

\section{References}

Agrios, G.N. (2005). Plant Pathology, $4^{\text {th }}$ edn. (London: Elsevier Academic Press).

Bartlett, D.W., Clough, J.M., Godwin, J.R., Hall, A.A., Hamer, M., and Parr-Dobrzanski, B. (2002). The strobilurin fungicides. Pest Manag. Sci. 58, 649-662. https://doi.org/10.1002/ps.520.

Brent, K.J., and Hollomon, D.W. (2007). Fungicide Resistance: the Assessment of Risk, $2^{\text {nd }}$ edn. (United Kingdom: Aimprint).

Fiaccadori, R. (2018). Persistence of Venturia inaequalis populations resistant to strobilurins in the field and in the glasshouse. Am. J. Plant Sci. 9, 552-560. https://doi.org/10.4236/ajps.2018.94042.

Fontaine, S., Remuson, F., Fraissinet-Tachet, L., Micoud, A., Marmeisse, R., and Melayah, D. (2009). Monitoring of Venturia inaequalis harbouring the QoI resistance G143A mutation in French orchards as revealed by PCR assays. Pest Manag. Sci. 65, 74-81. https://doi. org/10.1002/ps.1649.

Frederick, Z.A., Villani, S.M., Cooley, D.R., Biggs, A.R., Raes, J.J., and Cox, K.D. (2014). Prevalence and stability of qualitative QoI resistance in populations of Venturia inaequalis in the northeastern United States. Plant Dis. 98, 1122-1130. https://doi.org/10.1094/PDIS-10-131042-RE.

Gisi, U., Sierotzki, H., Cook, A., and McCaffery, A. (2002). Mechanisms influencing the evolution of resistance to Qo inhibitor fungicides. Pest Manag. Sci. 58, 859-867. https://doi.org/10.1002/ps.565.

Grasso, V., Palermo, S., Sierotzki, H., Garibaldi, A., and Gisi, U. (2006). Cytochrome $b$ gene structure and consequences for resistance to Qo inhibitor fungicides in plant pathogens. Pest Manag. Sci. 62, 465472. https://doi.org/10.1002/ps.1236.

MacHardy, W.E. (1996). Apple Scab: Biology, Epidemiology, and Management (St. Paul, MN: APS Press).

Manger-Jacob, F., Taufferner, T., and Mehl, A. (2016). VENTIN Pyro monitoring method Bayer. www.frac.info/monitoring-methods.

Michalecka, M., Malinowski, T., Broniarek-Niemiec, A., and Bielenin, A. (2011). Real-time PCR assay with SNP-specific primers for detection of a G143A mutation level in Venturia inaequalis field populations. J. Phytopathol. 159, 569-578. https://doi.org/10.1111/j.14390434.2011.01805.x.

Miessner, S., Koch, A., and Stammler, G. (2015). VENTIN PCR-RFLP monitoring method BASF. www.frac.info/monitoring-methods.
Sedlak, P., Vavra, R., Vejl, P., Bocek, S., and Kloutvorova, J. (2013). Efficacy loss of strobilurins used in protection against apple scab in Czech orchards. Hortic. Sci. 40, 45-51. https://doi. org/10.17221/22/2013-HORTSCI.

Sierotzki, H., Wullschleger, J., and Gisi, U. (2000a). Point-mutation in cytochrome $b$ gene conferring resistance to strobilurin fungicides in Erysiphe graminis f. sp. tritici field isolates. Pestic. Biochem. Physiol. 68, 107-112. https://doi.org/10.1006/pest.2000.2506.

Sierotzki, H., Parisi, S., Steinfeld, U., Tenzer, I., Poirey, S., and Gisi, U. (2000b). Mode of resistance to respiration inhibitors at the cytochrome $b c 1$ enzyme complex of Mycosphaerella fijiensis field isolates.PestManag.Sci.56,833-841.https://doi.org/10.1002/15264998(200010)56:10<833::AID-PS200>3.0.CO;2-Q.

Turan, C., Nanni, I.M., Tosun, N., and Collina, M. (2016). First report of QoI resistance in Venturia inaequalis causing apple scab in apple orchards in Turkey. Plant Dis. 100, 1016. https://doi.org/10.1094/ PDIS-10-15-1139-PDN.

Ypema, H.L., and Gold, R.E. (1999). Kresoxim-methyl: modification of a naturally occurring compound to produce a new fungicide. Plant Dis. 83, 4-19. https://doi.org/10.1094/PDIS.1999.83.1.4.

Received: Jan. 29, 2019

Accepted: Mar. 18, 2019

Address of authors:

Pavlina Jaklova, Jana Kloutvorova and Radek Cmejla* Research and Breeding Institute of Pomology Holovousy Ltd., Holovousy 129, Horice, 508 01,

Czech Republic

* Corresponding author; E-mail: radek.cmejla@vsuo.cz Tel.: +420 491848222 